\title{
Analisis Penerapan Metode Analytic Hierarchy Process (AHP) dalam Penentuan Daerah Tangkapan Air di Sub DAS Cisadane Hulu
}

\author{
Dina Paramitha Anggraeni HIDAYAT ${ }^{1}$ \\ ${ }^{1}$ Fakultas Teknik Sipil dan Perencanaan, Universitas Trisakti,email: dina.hidayat@trisakti.ac.id
}

Sejarah artikel

Diserahkan:

Dalam bentuk revisi: 15 September 2020

\author{
Diterima: $\quad 28$ September 2020 \\ Tersedia online: $\quad 30$ September 2020
}

\begin{abstract}
Groundwater catchment assessment is one of the important conservation actions to maintain the availability of surface and groundwater. One of the groundwater catchment assessment methods is used spatial data of watershed characteristics such as land use, rainfall, and slope. Those factors are assigned with weight value from various approaches. One of them is the AHP method. AHP has been developed and gave good results in water resources modeling. This research use Cisadane upstream watershed as a case study because of various watershed characteristics. Through AHP analysis, it is obtained that the slope factor has a greater priority weight than the land use and rainfall factors. The groundwater catchment of Cisadane upstream watershed is dominated with water catchment low to medium.
\end{abstract}

Keywords: AHP, watershed, spatial, catchment

\begin{abstract}
Abstrak
Penetapan daerah tangkapan air merupakan salah satu bagian dari upaya konservasi pada suatu DAS yang penting untuk menjaga keseimbangan air tanah dan air permukaan. Salah satu metode penetapan daerah tangkapan air adalah dengan menggunakan data spasial karakteristik DAS (tata guna lahan, curah hujan dan kemiringan lahan). Faktor karakteristik DAS tersebut diberikan bobot prioritas dengan berbagai pendekatan, salah satunya dengan metode AHP. Metode AHP telah banyak dikembangkan dan memberikan hasil yang cukup baik dalam pemodelan sumber daya air. Penelitian ini menggunakan Sub DAS Cisadane hulu sebagai lokasi penelitian karena memiliki karakteristik DAS yang bervariasi. Dari analisis dengan metode AHP, diperoleh faktor kemiringan memiliki bobot prioritas lebih besar dari faktor tata guna lahan dan curah hujan. Daerah tangkapan air yang dihasilkan pada Cisadane hulu didominasi oleh daerah tangkapan air rendah-sedang.
\end{abstract}

Kata kunci: AHP, DAS, spasial, tangkapan air

\section{Pendahuluan}

Ketersediaan air merupakan salah satu komponen penting bagi kehidupan manusia. Ketersediaan air terdiri dari 2 sumber yaitu air permukaan dan air tanah. Air tanah merupakan salah satu sumber utama untuk pemenuhan kebutuhan air, baik air minum, irigasi dan sebagainya (Balamurugan, Kumar and Shankar, 2020; Sobeih et al., 2017). Seiring dengan perkembangan suatu wilayah dan pertumbuhan penduduk yang pesat, terutama di DAS perkotaan terdapat permasalahan sumber daya air yaitu: ketidakseimbangan antara ketersediaan dan kebutuhan air (Elsayed Gabr, Soussa and Fattouh, 2020; Sobeih et al., 2017). Pada musim kemarau, debit di sungai sangat kecil bahkan cenderung kering, sedangkan pada musim hujan, banjir kerap terjadi terutama di daerah hilir dari suatu DAS. 
Salah satu penyebabnya adalah kurangnya resapan air pada DAS tersebut, karena adanya konversi tata guna lahan dari resapan air menjadi kedap air, sehingga tangkapan air pada DAS tersebut juga berkurang.

Penetapan daerah tangkapan air dapat dilakukan dengan metode pengukuran lapangan (filed survey), simulasi metode numerik dan penggunaan data spasial. Metode pengukuran lapangan cukup baik, namun membutuhkan waktu dan biaya yang lebih besar (H, Priju dan Prasad, 2015). Pemanfaatan data spasial melalui Sistem Informasi Geografis (GIS) telah banyak dikembangkan untuk analisis sumber daya air (Magesh, Chandrasekar and Soundranayagam, 2012). Penggunaan data spasial dapat dilakukan dengan beberapa pendekatan: logika fuzzy (Arumaikkani, Chelliah and Gopalan, 2017; Rafati and Nikeghbal, 2017), Analytic Hierarchy Process/AHP (Hossein, Ardakani and Ekhtesasi, 2016; Nithya et al., 2019), jaringan syaraf tiruan (Sokeng et al., 2016; Mayilvaganan and Naidu, 2011), dan multi influencing factor MIF (Thapa and Gupta, 2017; Etikala et al., 2019). Masing-masing pendekatan memiliki kelebihan dan kekurangan masing-masing. Logika fuzzy dan AHP memerlukan interpretasi dalam penetapan bobot pada masing-masing faktor yang dianalis, sedangkan jaringan syaraf tiruan (Artificial Neural Network) dapat menetapkan bobot faktor dengan pola data yang dianalisis, sehingga untuk metode ini memerlukan seri data yang cukup panjang.

Analisis air tanah dengan data spasial menggunakan berbagai faktor karakteristik DAS maupun faktor lain yang berpengaruh terhadap kondisi tangkapan dan resapan air. (Tiwari et al., 2017) menggunakan 7 faktor dalam analisis antara lain: kedalaman air permukaan, kemiringan lahan, kerapatan drainase, jenis tanah dan batuan, infiltrasi dan tata guna lahan. Penelitian ini membatasi faktor analisis untuk tangkapan air yaitu: kemiringan lahan, tata guna lahan dan curah hujan dengan klasifikasi menjadi: tangkapan rendah sampai dengan tangkapan tinggi. Penelitian ini menggunakan Sub DAS Cisadane hulu (dengan titik outlet pada Stasiun debit Batubeulah) sebagai studi kasus di Indonesia. Sub DAS Cisadane hulu merupakan bagian dari DAS Cisadane yang memiliki karakteristik DAS yang cukup beragam dari hulu sampai hilir. Penelitian ini diharapkan dapat menghasilkan daerah tangkapan air air Sub DAS Cisadane Hulu dengan metode AHP dan besarnya pengaruh masing-masing faktor bagi penetapan tangkapan air.

\section{Penentuan Daerah Tangkapan Air}

\section{Faktor Tangkapan Air}

Berdasarkan regulasi yang berlaku di Indonesia, terdapat 3 faktor yang dipertimbangkan sebagai faktor penentu tangkapan air, antara lain:

a. Curah hujan.

Daerah dengan curah hujan yang tinggi $(>3000 \mathrm{~mm} / \mathrm{th})$ akan memiliki potensi tangkapan air yang lebih tinggi dibandingkan dengan daerah yang curah hujannya rendah $(<500$ $\mathrm{mm} / \mathrm{th}$ ). Sub DAS Cisadane hulu memiliki curah hujan tahunan yang cukup tinggi $>3000$ $\mathrm{mm}$, oleh karena itu, pada penelitian ini faktor curah hujan memiliki 1 nilai klasifikasi spasial.

b. Topografi/Kemiringan lahan

Topografi daerah berupa cekungan akan memiliki potensi tangkapan air yang lebih tinggi daripada topografi punggung.

c. Tata guna lahan

Daerah dengan tataguna lahan hutan akan memiliki kemampuan tangkapan air yang lebih tinggi dibandingkan dengan daerah yang memiliki tataguna lahan permukiman.

\section{Metode Pendekatan Analisis Tangkapan Air}

Dari berbagai metode penentuan tangkapan air dengan pemanfaatan data spasial, seperti: jaringan syaraf tiruan, logika fuzzy, dan AHP, masing-masing memiliki kelebihan dan kelemahan sebagai berikut: 
a. AHP

Kelebihan : AHP dapat memberikan solusi bagi permasalahan yang kompleks dan dapat digunakan pada sistem yang saling bebas dan tidak harus memiliki hubungan linier antar elemen. Kelemahan: AHP memiliki ketergantungan hasilnya pada subjektivitas persepsi dalam pemberian bobotnya. Pada penelitian ini bobot yang digunakan menggunakan bobot dari penelitian terdahulu.

b. Jaringan syaraf tiruan (Artificial Neural Network)

Kelebihan : Pendekatan Jaringan Syaraf Tiruan mampu melakukan generalisasi dari suatu pola data tertentu dan dapat menciptakan suatu pola pengetahuan melalui proses pembelajaran (training) dan menghasilkan bobot-bobot sesuai pola data tertentu (tidak menggunakan asumsi). Kelemahan: Jumlah hidden layer akan mempengaruhi akurasi model dan lamanya proses pembelajaran, data pembelajaran yang dibutuhkan cukup banyak untuk menghasilkan model dengan hasil validasi yang baik.

c. Logika fuzzy (Fuzzy Logic)

Kelebihan : Logika fuzzy dapat mengekspresikan dan memberikan solusi permasalahan yang sulit dirumuskan dengan menggunakan logika yang memungkinkan untuk melakukan observasi objektif terhadap nilai yang bersifat subjektif. Kelemahan: Terdapat kesulitan untuk menentukan kepastian nilai fungsi keanggotaan, batas parameter dan fungsi implikasi fuzzy yang sesuai untuk menghasilkan data yang akurat, karena bergantung dari keahlian/pakar.

\section{Metodologi}

Berikut ini disajikan diagram alir pelaksanaan penelitian ini.

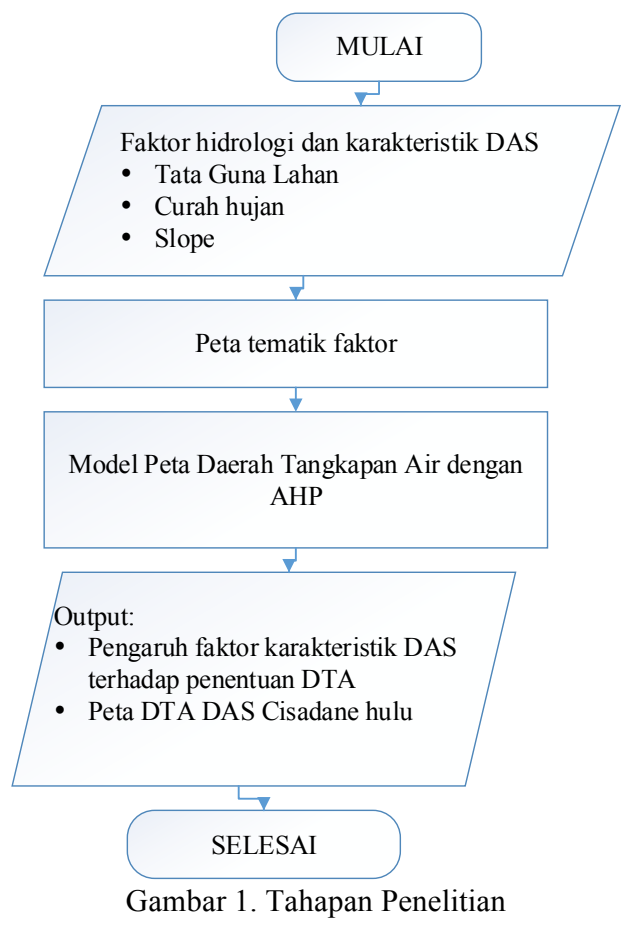

Secara garis besar, terdapat 3 tahapan pada penelitian ini,antara lain:

- Pengumpulan data

Data yang diperlukan sebagai data masukan dalam penelitian ini, meliputi:

$\checkmark$ Data DEM topografi, digunakan untuk membentuk batas DAS dan analisis besarnya kemiringan lahan Sub DAS Cisadane. Data DEM yang digunakan merupakan data yang berasal dari SRTM (Shuttle Radar Topography Mission)

$\checkmark$ Data tata guna lahan digunakan untuk membentuk peta pembobotan faktor tata guna lahan.

$\checkmark$ Data hidroklimatologi digunakan untuk melihat variasi curah hujan tahunan pada sub DAS Cisadane hulu. 
- Analisis faktor tangkapan air

Pembuatan peta pembobotan masing-masing faktor tangkapan air dilakukan dengan metode AHP sesuai klasifikasi spasial dari faktor tersebut. Faktor tata guna lahan, kemiringan dan curah hujan masing-masing dibagi menjadi 5 klasifikasi.

- Zonasi tangkapan air

Setelah peta pembobotan masing-masing faktor telah dibentuk, kemudian ditetapkan pembobotan sesuai dengan metode AHP, dan dilakukan proses tumpang tindih (overlay) untuk membuat zona tangkapan air.

\section{Analisis dan Pembahasan}

\section{Deskripsi Wilayah Studi}

Lingkup wilayah penelitian ini adalah DAS Cisadane hulu dengan titik outlet pada stasiun pengukuran debit Batubeulah. DAS Cisadane terbagi menjadi 3 Sub DAS, Sub DAS Cisadane hulu, Sub DAS Cisadane tengah dan Sub DAS Cisadane hilir. DAS Cisadane hulu dengan luas $112.000 \mathrm{Ha}$ termasuk dalam wilayah administrasi Kabupaten Bogor dan sebagian kecil Kota Bogor serta sebagian kecil kecamatan di Kabupaten Sukabumi.

\section{$\underline{\text { Kondisi Iklim }}$}

Kondisi klimatologi DAS Cisadane hulu diperoleh dari stasiun klimatologi Dramaga, dengan suhu rata-rata $25,73^{\circ} \mathrm{C}$, lama penyinaran rata-rata $69,84 \%$, kelembapan udara rata-rata $80,70 \%$ dan kecepatan angin 3,33 knot.

Tabel 1. Kondisi iklim Sub DAS Cisadane Hulu

\begin{tabular}{|c|c|c|c|c|}
\hline \multirow{3}{*}{ Bulan } & \multicolumn{4}{|c|}{ Stasiun Dramaga } \\
\hline & Suhu & Lama penyinaran & Kelembaban Udara & Kecepatan Angin \\
\hline & $\left({ }^{0} \mathrm{C}\right)$ & $(\%)$ & $(\%)$ & (knot) \\
\hline Jan & 25.3 & 68.3 & 82.9 & 3 \\
\hline Feb & 25.5 & 53.9 & 83 & 4 \\
\hline Mar & 25.7 & 59.1 & 80.5 & 3 \\
\hline Apr & 25.9 & 71.3 & 86.9 & 2 \\
\hline Mei & 26.1 & 77.4 & 86.05 & 3 \\
\hline Jun & 25.8 & 75.2 & 80.55 & 3 \\
\hline Jul & 25.2 & 80.8 & 80.15 & 4 \\
\hline Ags & 25.5 & 79.6 & 74.05 & 4 \\
\hline Sep & 26 & 84.3 & 77.65 & 4 \\
\hline Okt & 26.2 & 79.4 & 81.1 & 4 \\
\hline Nov & 25.8 & 54.8 & 70.3 & 3 \\
\hline Des & 25.7 & 54 & 85.25 & 3 \\
\hline Rata-Rata & 25.73 & 69.84 & 80.70 & 3.33 \\
\hline
\end{tabular}

sumber :(Sudinda, 2020)

\section{Kondisi Hidrologi (curah hujan)}

Curah hujan DAS Cisadane hulu diperoleh dari data stasiun hujan Kracak dengan curah hujan bulanan rata-rata terbesar pada bulan Mei sebesar $442 \mathrm{~mm}$ dan terkecil pada bulan Juli sebesar $159 \mathrm{~mm}$. 


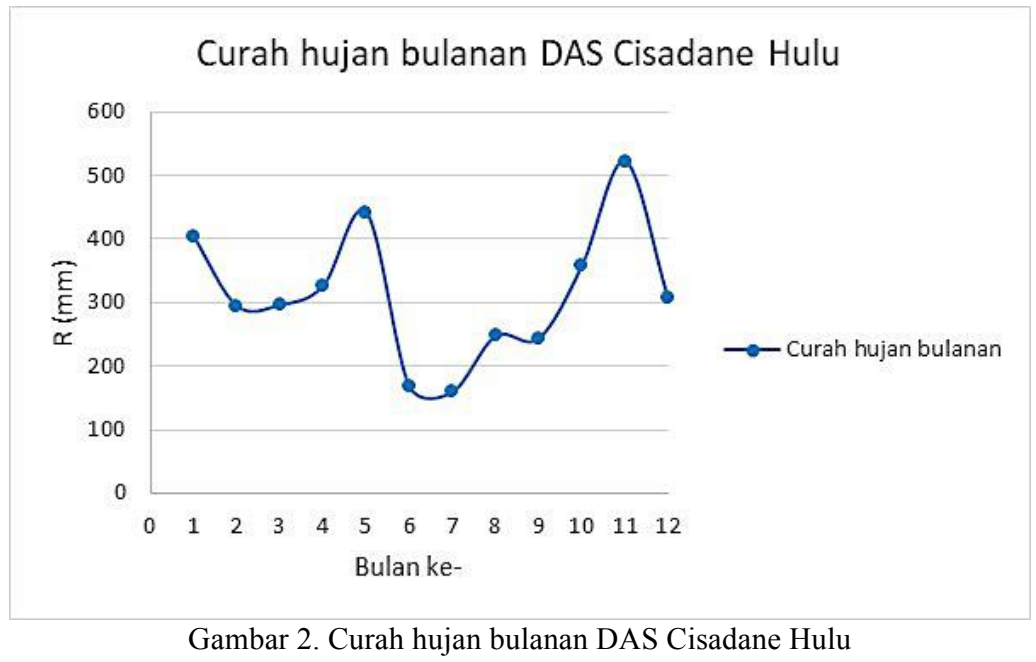

Debit sungai

Pengukuran debit Sungai Cisadane hulu diperoleh dari stasiun debit Batubeulah. Nilai debit yang digunakan diperoleh dari pengukuran tinggi muka air yang kemudian dikonversi menjadi debit. Pengukuran tinggi muka air dilakukan 3 kali dalam sehari yakni pada pagi hari pukul 06.00, siang hari pukul 12.00 dan sore hari pukul 18.00, dan kemudian dilakukan perhitungan tinggi muka air rata-rata per hari.

\section{STASIUN BATUBEULAH}

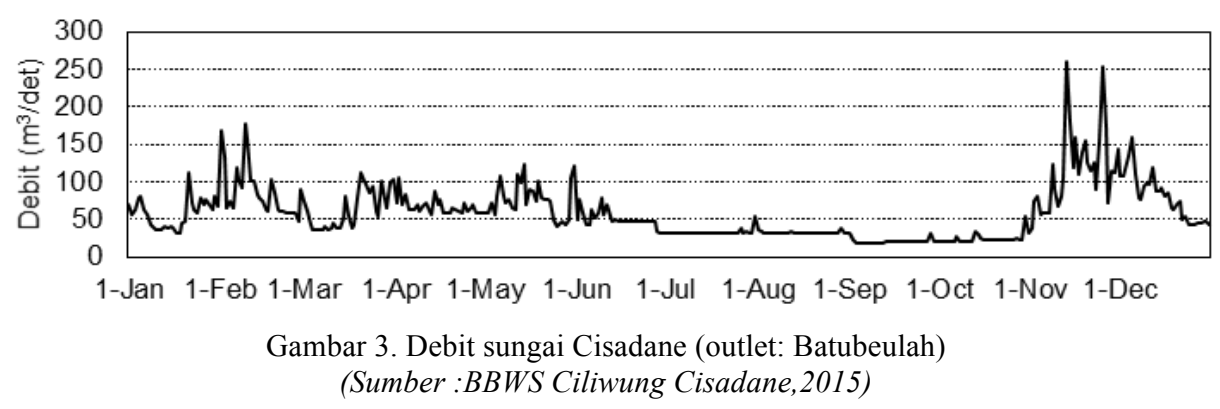

\section{Analisis Faktor Resapan Air}

\section{Kemiringan Lahan}

Kemiringan lahan (slope) DAS Cisadane curam pada bagian hulu dan relatif landai-datar pada bagian tengah dan hilir. Bobot nilai yang diberikan pada masing-masing kriteria spasial kemiringan ditampilkan melalui tabel sebagai berikut:

Tabel 2. Bobot AHP faktor kemiringan lahan

\begin{tabular}{|c|c|c|c|c|c|c|c|}
\hline $\begin{array}{c}\text { Klasifikasi spasial } \\
\text { slope }\end{array}$ & $\mathbf{0 \% - 8 \%}$ & $\mathbf{8 \%}-\mathbf{1 5 \%}$ & $\mathbf{1 5 \%} \mathbf{- 2 5 \%}$ & $\mathbf{2 5 \%}-\mathbf{4 0 \%}$ & $\mathbf{7 4 0 \%}$ & Rata-rata & $\begin{array}{c}\text { Bobot } \\
\text { prioritas }\end{array}$ \\
\hline $0 \%-8 \%$ & 1 & 5 & 7 & 8 & 9 & 6 & 0.34 \\
\hline $8 \%-15 \%$ & 1.5 & 1 & 5 & 7 & 8 & 4.5 & 0.26 \\
\hline $15 \%-25 \%$ & 1.7 & 1.5 & 1 & 5 & 7 & 3.24 & 0.18 \\
\hline $25 \%-40 \%$ & 1.8 & 1.7 & 1.5 & 1 & 5 & 2.2 & 0.13 \\
\hline$>40 \%$ & 1.9 & 1.8 & 1.7 & 1.5 & 1 & 1.58 & 0.09 \\
\hline
\end{tabular}

\section{Tata Guna Lahan}

Tata guna lahan DAS Cisdane hulu didominasi oleh hutan dan lahan pertanian, namun terdapat kecenderungan perubahan tata guna lahan dari daerah resapan air menjadi daerah kedap air. 
JURNAL REKAYASA KONSTRUKSI MEKANIKA SIPIL (JRKMS)

Vol. 03 No. 02 September 2020

Tabel 3. Bobot AHP faktor tata guna lahan

\begin{tabular}{|c|c|c|c|c|c|c|c|}
\hline Tata guna lahan & Hutan & $\begin{array}{c}\text { Lahan } \\
\text { Terbuka }\end{array}$ & Pertanian & Badan Air & Pemukiman & Rata-rata & $\begin{array}{c}\text { Bobot } \\
\text { prioritas }\end{array}$ \\
\hline Hutan & 1 & 2 & 3 & 4 & 5 & 3 & 0.31 \\
\hline Lahan Terbuka & 1.2 & 1 & 2 & 3 & 4 & 2.24 & 0.23 \\
\hline Pertanian & 1.3 & 1.2 & 1 & 2 & 3 & 1.7 & 0.18 \\
\hline Badan Air & 1.4 & 1.3 & 1.2 & 1 & 2 & 1.38 & 0.14 \\
\hline Pemukiman & 1.5 & 1.4 & 1.3 & 1.2 & 1 & 1.28 & 0.13 \\
\hline
\end{tabular}

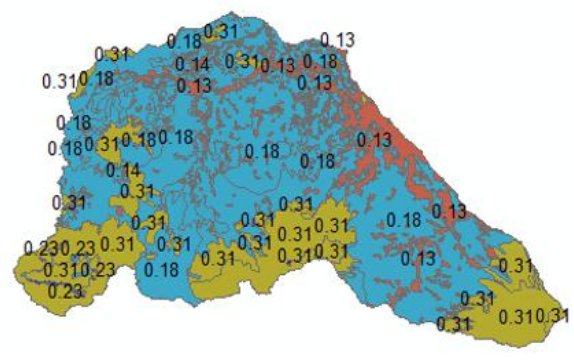

(a)

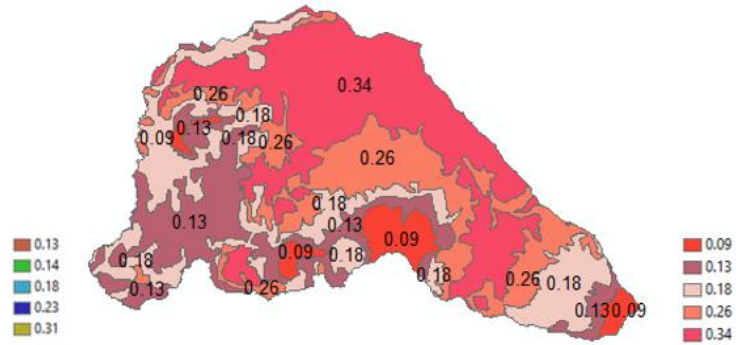

(b)

Gambar 4. Peta tematik faktor tangkapan air (a) Tata guna lahan (b) Kemiringan lahan

\section{Analisis Daerah Tangkapan Air dengan metode AHP}

Berbagai penelitian terdahulu telah mengembangkan metode AHP dengan data spasial karakteristik DAS untuk menganalisis air tanah (Patra, Mishra and Mahapatra, 2018; Das and Pal, 2019). Pembobotan faktor hidrologi dan karakteristik DAS dengan metode AHP yang menghasilkan bobot terbesar adalah faktor kemiringan dengan bobot 0,44 , faktor curah hujan sebesar 0,30 dan tata guna lahan sebesar 0,26. Dari hasil tumpang tindih antar faktor, Sub DAS Cisadane memiliki potensi tangkapan air rendah-tinggi, dengan dominasi potensi tangkapan air tinggi pada daerah lebih hilir daripada potensi tangkapan air rendah. Sub DAS Cisadane hulu lebih berpotensi sebagai daerah resapan air daripada daerah tangkapan air.

Tabel 4. Bobot prioritas antar faktor metode AHP

\begin{tabular}{|c|c|c|c|c|c|}
\hline Faktor & Kemiringan & Curah Hujan & Tata guna lahan & Rata-rata & Bobot prioritas \\
\hline Kemiringan & 1 & 2 & 3 & 2.00 & 0.44 \\
\hline Curah Hujan & 1.2 & 1 & 2 & 1.40 & 0.30 \\
\hline Tata guna lahan & 1.3 & 1.2 & 1 & 1.17 & 0.26 \\
\hline
\end{tabular}

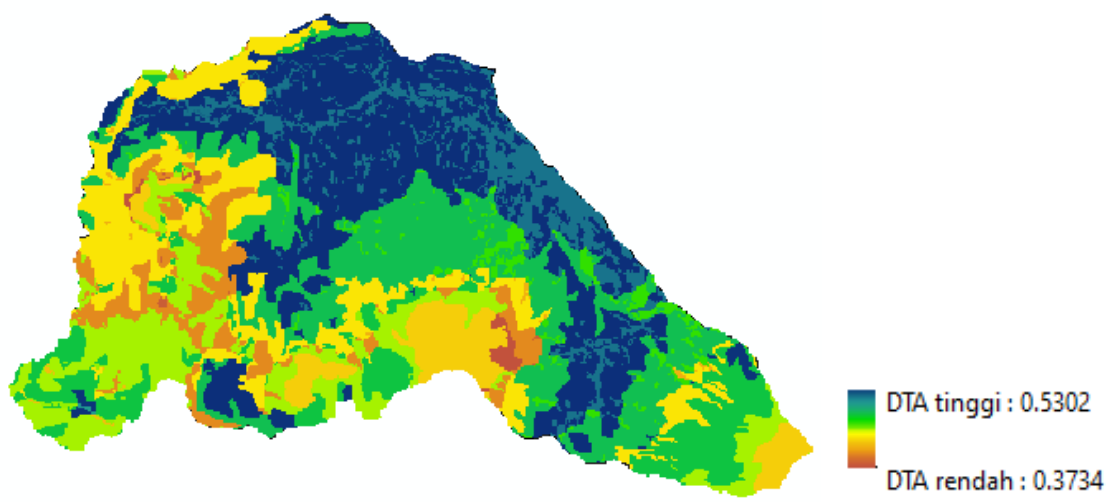

Gambar 5. Peta daerah tangkapan air Sub DAS Cisadane hulu

\section{Kesimpulan}

Beberapa kesimpulan yang dapat diambil dari penelitian ini dijelaskan sebagai berikut. Kemiringan lahan (slope) DAS Cisadane curam pada bagian hulu dan relatif landai-datar pada bagian tengah dan hilir. Tata guna lahan DAS Cisadane hulu didominasi oleh hutan dan lahan pertanian, namun terdapat kecenderungan perubahan tata guna lahan dari daerah resapan air menjadi daerah kedap air. Sub DAS Cisadane hulu memiliki curah hujan tahunan 
yang cukup tinggi $>3000 \mathrm{~mm}$. Pembobotan faktor hidrologi dan karakteristik DAS dengan metode AHP menghasilkan bobot terbesar adalah faktor kemiringan dengan bobot 0,44. Sub DAS Cisadane memiliki potensi tangkapan air rendah-tinggi, dengan dominasi potensi tangkapan air tinggi pada daerah lebih hilir daripada potensi tangkapan air rendah. Sub DAS Cisadane hulu lebih berpotensi sebagai daerah resapan air daripada daerah tangkapan air

\section{Referensi}

Arumaikkani, G. S., Chelliah, S. and Gopalan, M. (2017) 'Revelation of groundwater possible region using fuzzy logic based GIS modeling', International Journal of Applied Engineering Research, 12(22), pp. 12176-12183.

Balamurugan, P., Kumar, P. S. and Shankar, K. (2020) 'Dataset on the suitability of groundwater for drinking and irrigation purposes in the Sarabanga River region, Tamil Nadu, India', Data in Brief. Elsevier Ltd, 29, p. 105255. doi: 10.1016/j.dib.2020.105255.

Das, B. and Pal, S. C. (2019) 'Combination of GIS and fuzzy-AHP for delineating groundwater recharge potential zones in the critical Goghat-II block of West Bengal, India', HydroResearch. The Authors, 2, pp. 21-30. doi: 10.1016/j.hydres.2019.10.001.

Elsayed Gabr, M., Soussa, H. and Fattouh, E. (2020) 'Groundwater quality evaluation for drinking and irrigation uses in Dayrout city Upper Egypt', Ain Shams Engineering Journal. THE AUTHORS, (xxxx). doi: 10.1016/j.asej.2020.05.010.

Etikala, B. et al. (2019) 'Deciphering groundwater potential zones using MIF technique and GIS: A study from Tirupati area, Chittoor District, Andhra Pradesh, India', HydroResearch. The Authors, 1, pp. 1-7. doi: 10.1016/j.hydres.2019.04.001.

H, Y. A., Priju, C. P. and Prasad, N. B. N. (2015) 'Delineation of Groundwater Potential Zones in Deep Midland Aquifers along Bharathapuzha River Basin , Kerala using Geophysical Methods', Aquatic Procedia. Elsevier B.V., 4(Icwrcoe), pp. 1039-1046. doi: 10.1016/j.aqpro.2015.02.131.

Hossein, A., Ardakani, H. and Ekhtesasi, M. R. (2016) 'Groundwater potentiality through Analytic Hierarchy Process ( AHP ) using remote sensing and Geographic Information System ( GIS )', JGeope, 6(1), pp. 75-88.

Magesh, N. S., Chandrasekar, N. and Soundranayagam, J. P. (2012) 'Delineation of groundwater potential zones in Theni district, Tamil Nadu, using remote sensing, GIS and MIF techniques', Geoscience Frontiers. Elsevier B.V., 3(2), pp. 189-196. doi: 10.1016/j.gsf.2011.10.007.

Mayilvaganan, M. K. and Naidu, K. B. (2011) 'ANN and Fuzzy Logic Models for the Prediction of groundwater level of a watershed', International Journal on Computer Science and Engineering, $3(6)$, pp. 2523-2530.

Nithya, C. N. et al. (2019) 'Assessment of groundwater potential zones in Chittar basin, Southern India using GIS based AHP technique', Remote Sensing Applications: Society and Environment. Elsevier B.V., 15(March), p. 100248. doi: 10.1016/j.rsase.2019.100248.

Patra, S., Mishra, P. and Mahapatra, S. C. (2018) 'Delineation of groundwater potential zone for sustainable development: A case study from Ganga Alluvial Plain covering Hooghly district of India using remote sensing, geographic information system and analytic hierarchy process', Journal of Cleaner Production. Elsevier B.V., 172, pp. 2485-2502. doi: 10.1016/j.jclepro.2017.11.161.

Rafati, S. and Nikeghbal, M. (2017) 'Groundwater exploration using fuzzy logic approach in GIS for an area around an anticline, Fars Province', International Archives of the Photogrammetry, Remote Sensing and Spatial Information Sciences - ISPRS Archives, 42(4W4), pp. 441-445. doi: 10.5194/isprs-archives-XLII-4-W4-441-2017.

Sobeih, M. M. et al. (2017) 'Management of water resources to control groundwater levels in the southern area of the western Nile delta, Egypt', Water Science. COPYRIGHT.TEXT=National Water Research Center, 31(2), pp. 137-150. doi: 10.1016/j.wsj.2017.09.001.

Sokeng, V. J. et al. (2016) 'Delineating groundwater potential zones in Western Cameroon Highlands using GIS based Artificial Neural Networks model and remote sensing data Delineating groundwater potential zones in Western Cameroon Highlands using GIS based Artificial Neural Networks', (June).

Sudinda, T. W. (2020) 'Penentuan Debit Andalan Dengan Metoda Fj Mock Di Daerah Aliran Sungai Cisadane', Jurnal Air Indonesia, 11(1), pp. 15-24. doi: 10.29122/jai.v11i1.3933.

Thapa, R. and Gupta, S. (2017) 'Assessment of groundwater potential zones using multi-influencing factor ( MIF ) and GIS : a case study from Birbhum district, West Bengal', Applied Water Science. Springer Berlin Heidelberg, 7(7), pp. 4117-4131. doi: 10.1007/s13201-017-0571-z.

Tiwari, A. K. et al. (2017) 'Identification of artificial groundwater recharging zone using a GIS-based fuzzy logic approach: a case study in a coal mine area of the Damodar Valley, India', Applied Water Science. Springer Berlin Heidelberg, 7(8), pp. 4513-4524. doi: 10.1038/104532a0. 


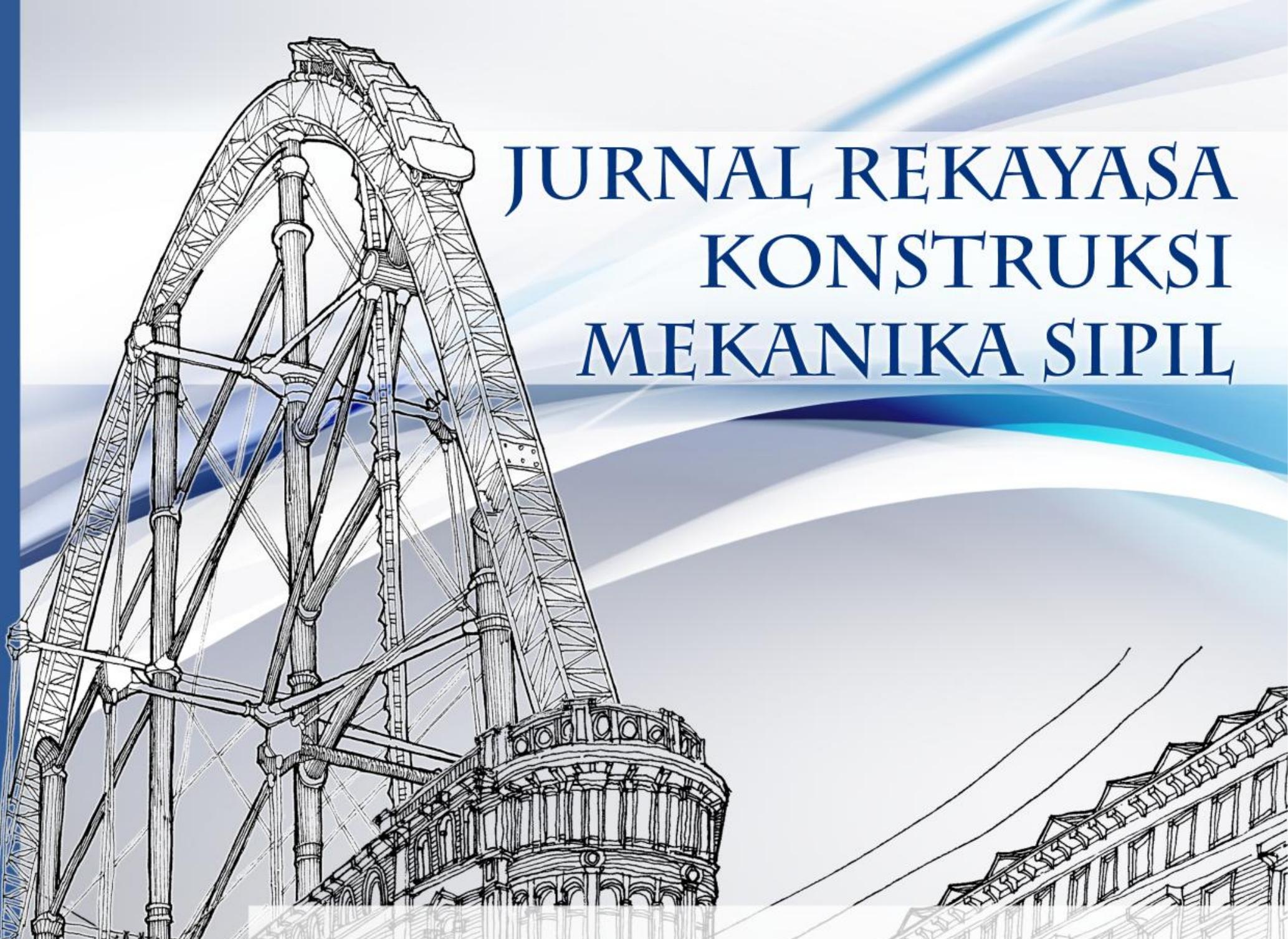

Analisa Perilaku Balok Beton Bertulang dengan Menggunakan Simulasi VecTor2

Sudarno P. TAMPUBOLON

Review Faktor - Faktor Yang Mempengaruhi Karakteristik Kuat Tekan Beton Geopolimer

Putrilyan Ezra PANJAITAN \& Liana HERLINA

Analisis Penerapan Metode Analytic Hierarchy Process (AHP) dalam Penentuan

Daerah Tangkapan Air di Sub DAS Cisadane Hulu

Dina Paramitha Anggraeni HIDAYAT

Dampak Pandemi Covid-19 Terhadap Tingkat Pelayanan Moda Transportasi

Speedboat Tidore-Sofifi

Abdul GAUS, Mufti Amir SULTAN, Iis Hamsir Ayub WAHAB, Abdul Majid ABDULLAH,

\& Nu'man NU'MAN

Analisis Proyeksi Jadwal Dan Biaya Akhir Dengan Konsep Nilai Hasil Pada Proyek Konstruksi

Silvia Yulita RATIH \& Dody IRNAWAN

Fakultas Teknik

Universitas Katolik Santo Thomas

JI. Setia Budi No. 479-F Tanjung Sari, Medan 


\section{Jurnal Rekayasa Konstruksi Mekanika Sipil (JRKMS)}

Jurnal Rekayasa Konstruksi Mekanika Sipil (JRKMS) diterbitkan oleh Fakultas Teknik Universitas Katolik Santo Thomas. JRKMS berisi artikel-artikel ilmiah yang meliputi kajian di bidang Teknik khususnya Teknik Sipil seperti Matematika teknik, Mekanika teknik, Analisis struktur, Konstruksi baja, Konstruksi beton, Konstruksi kayu, Konstruksi gelas, Mekanika tanah, Teknik Pondasi, Hidrologi, Hidrolika, Bangunan air, Manajemen konstruksi, Dinamika Struktur, Earthquake Engineering, Informatika, Ilmu Ukur Tanah, Struktur bangunan sipil, Rekayasa Jalan Raya, serta penelitian-penelitian lain yang terkait dengan bidang-bidang tersebut.

Terbit dalam 2 (dua) kali setahun yaitu pada bulan April dan September

Penasehat :

Prof. Dr. Drs. Sihol Situngkir, MBA. (Rektor UNIKA)

\section{Ketua Penyunting :}

Ir. Oloan Sitohang, M.T. (Universitas Katolik Santo Thomas)

Manajer Jurnal :

Reynaldo, S.T., M.Eng. (Universitas Katolik Santo Thomas)

\section{Anggota Penyunting :}

Medis Sejahtera Surbakti, S.T, M.T., Ph.D. (Universitas Sumatera Utara)

Dr. Janner Simarmata (Universitas Negri Medan)

Ir. Martius Ginting, M.T. (Universitas Katolik Santo Thomas)

Samsuardi Batubara, S.T., M.T. (Universitas Katolik Santo Thomas)

\section{Mitra Bestari :}

Dr.Eng. Aleksander Purba (Universitas Lampung, Indonesia)

Ir. Binsar Silitonga, M.T. (Universitas Katolik Santo Thomas, Indonesia)

Ir. Charles Sitindaon, M.T. (Universitas Katolik Santo Thomas, Indonesia)

Dr. Erica Elice Uy (De La Salle University, Philippines)

Dr. Harijanto Setiawan (Universitas Atma Jaya Yogyakarta, Indonesia)

Dr.Eng. Jeffry Swingly Frans Sumarauw (Universitas Sam Ratulangi, Indonesia)

Prof. Dr-Ing. Johannes Tarigan (Universitas Sumatera Utara, Indonesia)

Linda Prasetyorini (Universitas Brawijaya, Malang, Indonesia)

Dr.Eng. Mia Wimala (Universitas Katolik Parahyangan, Indonesia)

Dr.Eng. Minson Simatupang (Universitas Halu Oleo, Indonesia)

Dr. Mochamad Raditya Pradana (Keppel Marine and Deepwater Technology, Singapura)

Dr. Senot Sangadji (Universitas Sebelas Maret, Indonesia)

Ir. Simon Dertha, M.T. (Universitas Katolik Santo Thomas, Indonesia)

Dr. Thi Nguyên Cao (Tien Giang University, Viet Nam)

\section{Ilustrator Sampul:}

Yulianto, ST., M.Eng

\section{Penerbit \& Alamat Redaksi:}

Fakultas Teknik Universitas Katolik Santo Thomas

J1. Setiabudi No. 479-F Tanjung Sari, Medan 20132

Telp. (061) 8210161 Fax : (061) 8213269

email : unika.sipil@yahoo.com 


\section{Konten}

REKAYASA STRUKTUR

Analisa Perilaku Balok Beton Bertulang dengan Menggunakan Simulasi VecTor2

Sudarno P. TAMPUBOLON

Review Faktor - Faktor Yang Mempengaruhi Karakteristik Kuat Tekan Beton Geopolimer

Putrilyan Ezra PANJAITAN \& Liana HERLINA

TEKNIK SUMBER DAYA AIR

Analisis Penerapan Metode Analytic Hierarchy Process (AHP) dalam

Penentuan Daerah Tangkapan Air di Sub DAS Cisadane Hulu

Dina Paramitha Anggraeni HIDAYAT

\section{REKAYASA TRANSPORTASI}

Dampak Pandemi Covid-19 Terhadap Tingkat Pelayanan Moda

Transportasi Speedboat Tidore-Sofifi

Abdul GAUS, Mufti Amir SULTAN, Iis Hamsir Ayub WAHAB, Abdul Majid

ABDULLAH, \& Nu'man NU'MAN

\section{MANAJEMEN KONSTRUKSI}

Analisis Proyeksi Jadwal Dan Biaya Akhir Dengan Konsep Nilai Hasil Pada

Proyek Konstruksi

Silvia Yulita RATIH \& Dody IRNAWAN hal.

55-64

89-96

97-106 


\section{Pengantar Redaksi}

Puji dan syukur kami sampaikan kepada Tuhan Yang Maha Esa karena atas rahmatNya kami dapat menyelesaikan penerbitan Jurnal Rekayasa Konstruksi Mekanika Sipil (JRKMS) Volume 3 Nomor 2, di bulan September tahun 2020 ini. Jurnal ini fokus pada beragam subbidang dalam Teknik Sipil, yakni Rekayasa Struktur, Rekayasa Geoteknik, Rekayasa Transportasi, Teknik Sumber Daya Air, dan Manajemen Konstruksi. Namun, tidak menutup kesempatan bagi subbidang lainnya yang berkaitan dengan bidang Teknik Sipil. Pada tahun ke-3 terbitnya, JRKMS telah menerima terakreditasi ARJUNA dengan peringkat Sinta S5.

Meski masih dalam kondisi pandemi COVID-19, penelitian tetap harus dijalankan dan produktivitas peneliti di Indonesia masih harus terus berkembang. Dalam edisi ini, terdapat 5 artikel yang terdiri atas dua (2) artikel dalam topik Rekayasa Struktur, satu (1) artikel dalam topik Teknik Sumber Daya Air, satu (1) artikel dalam topik Rekayasa Transportasi, dan satu (1) artikel dalam topik Manajemen Konstruksi. Redaksi/Tim editorial memiliki kerinduan agar semakin banyak peneliti yang menerbitkan karya berkualitasnya di JRKMS untuk mendukung pengembangan wawasan dalam dunia teknik sipil. Apresiasi kami berikan kepada penulis yang tulisannya diterbitkan pada Vol.03 No.02 September 2020 ini karena telah menginvestasikan waktu dalam menuangkan ide dan merespon masukan dari mitra bestari hingga karyanya siap untuk diterbitkan.

Sebagai penutup, yang menjadi harapan tim editorial adalah semoga jurnal ini dapat menjadi media ilmiah yang berguna bagi civitas akademika, dan perkembangan ilmu pengetahuan serta penelitian di bidang ilmu ketekniksipilan di Indonesia. Salam hangat. Salam sehat.

September 2020

Tim Editorial 
JURNAL REKAYASA KONSTRUKSI MEKANIKA SIPIL | Volume 03 | No. 02 | September 2020 | Jurnal IImiahTeknik Sipil Fakultas Teknik Universitas Katolik Santo Thomas ejournal.ust.ac.id/index.php/JRKMS

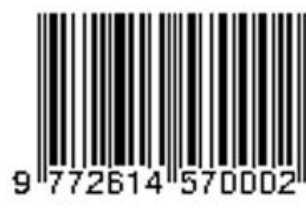

Google A GARUDA ISJDNeo : neliti Donesearch PBase 